\title{
Caregivers of cancer patients: what are their information-seeking behaviours and resource preferences?
}

\author{
Gek Phin Chua ${ }^{1}$, Quan Sing Ng², Hiang Khoon $\operatorname{Tan}^{3}$ and Whee Sze Ong ${ }^{4}$ \\ ${ }^{1}$ Cancer Education and Information Service (Research \& Data), National Cancer Centre Singapore, 169610 Singapore \\ 2Division of Medical Oncology, National Cancer Centre Singapore, 169610 Singapore \\ ${ }^{3}$ Division of Surgery and Surgical Oncology, National Cancer Centre Singapore, 169610 Singapore \\ ${ }^{4}$ Division of Clinical Trails and Epidemiological Sciences, National Cancer Centre Singapore, 169610 Singapore
}

\section{Abstract}

Cancer impacts not only the patient but also the family members who share the distressing trajectory of the patient. The literature indicates that caregivers have many unmet information needs while providing care and support to the cancer patients, and caregivers have to resort to seeking information to supplement their information needs. This study aims to establish the prevalence of health-information-seeking behaviours among caregivers of cancer patients as a means of ascertaining if their information needs have been met and their information source and resource preference. Data were obtained via a self-reported questionnaire from caregivers of cancer patients at the National Cancer Centre Singapore between 10 September and 7 December 2018. A total of 986 caregivers responded of which 180 (18\%) caregivers did not undertake information search and the common reasons were 'trust healthcare professionals' (HCPs) more than other sources (64\%), and 'HCPs provide enough information' (59\%). Among the 795 caregivers who have searched for cancer information, about half of these caregivers (54\%) have searched information on the Internet and another 15\% have obtained their information from HCPs in their most recent search. A total of 371 (47\%) caregivers have used their preferred source of information to conduct their most recent information search. The top three most commonly sought information was treatment (35.6\%), disease $(35.6 \%)$ and side effects (26.5\%). Almost half (46\%) of these caregivers was concerned about the quality of information they have found on the Internet. Our study supports that informationseeking is prevalent amongst caregivers of cancer patients and reveals the prevalence of Internet use and the concerns associated with its use. Patterns of information-seeking revealed a discrepancy between preferred and actual source. The results also suggest that HCPs play a significant role in the information-seeking behaviours of caregivers of cancer patients.

Keywords: caregivers, cancer, information sources, Internet, trust

Correspondence to: Gek Phin Chua Email: chuagekphin2@gmail.com

ecancer 2020, 14:1068

https://doi.org/10.3332/ecancer.2020.1068

Published: $10 / 07 / 2020$

Received: 05/12/2019

Publication costs for this article were supported by ecancer (UK Charity number 1176307).

Copyright: (c) the authors; licensee ecancermedicalscience. This is an Open Access article distributed under the terms of the Creative Commons Attribution License (http:// creativecommons.org/licenses/by/3.0), which permits unrestricted use, distribution, and reproduction in any medium, provided the original work is properly cited. 


\section{Background}

Cancer impacts not only the patient but also the family members who share the distressing trajectory of the patient [1-3]. It disrupts family dynamics and changes roles and daily functioning [4]. Care responsibilities comprises both tangible assistance such as preparing meals for patients, providing transportation, helping with medication, communicating with doctors, and assessing the need for medication and treatment and intangible assistance, such as providing emotional, financial, social and spiritual support $[5,6]$. Compounded to these is a shift responsibility for providing the tasks that often require a high degree of technical and observational skills that were previously provided by healthcare professionals (HCPs) to family members due to the shift in therapeutic management and treatment of cancer on an outpatient basis.Caring for patients with cancer is, therefore, a complex and demanding role and as such, caregivers of cancer patients experience a lot of distress [7-9] and burden [3, 5, 10,11]. The distress and burden for caring for a person with cancer may be higher than Western society due to the Asian context where families are more involved in caring for one another. Asian society promotes social cohesion and interdependence where the family members are far more involved in caring for its members. Families are expected to care and support one another, especially the elderly, sick or disabled.

Caregiver needs have been well described in the literature and predominantly relate to information needs and psychological or emotional support [12-16]. Studies indicate that caregivers of cancer patients needed information on the disease, prognosis, treatment, and expected side effects and their management, hands-on care skills and accessing and navigating the healthcare system, including resources [5, 8, 12]. Information has been found to be helpful in assisting caregivers to cope by reducing the feeling of uncertainty [17]. However, these information needs are often unmet $[7,12-15,18]$ and caregivers have to resort to seeking information to supplement their information needs [8, 16, 19]. The source of which family caregivers receive health information and the extent of how much they comprehend health information is crucial to achieving the best possible health outcomes as evidence revealed that they resorted to alternative mode of treatments to control symptoms and adverse effects of treatment [8] when their needs were unmet.

The research indicates that the Internet has been a common source for patients and caregivers to seek health information [20-25]. The common reasons cited for its use are convenience, amount of information available, immediacy of access, current and reliable information and privacy and anonymity [26, 27]. However, concerns have been raised about the quality of health information that is being posted online and whether information seekers possess the ability to effectively search, comprehend and discern the voluminous and highly variable quality of information $[28,29]$.

Since caregivers play a crucial role in supporting and caring for the cancer patient, and their ability to render care and support may be compromised by their lack of knowledge and skill, the role of health-information-seeking behaviour and resource preference have in caregivers' needs can expand understanding of caregiver needs and is an essential step in achieving the goal of meeting their information needs. Such understanding can be used to inform the development of effective family caregiver education interventions to better deliver information in a manner that best meet their needs and preferences. Although studies have established the informational needs of caregivers of cancer patients; however, there was differing viewpoints on the type and amount of information they require $[8,12,15,18]$. Besides, studies on information-seeking behaviours were mostly limited to the use of Internet [23-25], and there is a dearth of information on their informationseeking behaviours and their preferred source to receive information. As there is no reported study done on the information-seeking behaviours of caregivers of cancer patients in Singapore, this study seeks to establish the prevalence of health-information-seeking behaviours among caregivers of cancer patient and their resource preference in order to guide practice.

\section{Methods}

\section{Study conduct and analysis}

This study was a part of a larger survey on the unmet needs and quality of life of caregivers of cancer patients in Singapore. The study was conducted at the National Cancer Centre Singapore (NCCS) using the SPUNS-SF and the CQOLC-S25 between 10 September and 7 
December 2018.The study population was caregivers of cancer patients who were defined as unpaid individuals who might be the parents, children, spouses, relatives or friends, providing one or more activities of daily living and healthcare needs for the cancer patients. Eligibility criteria for participation in the survey were: (1) able to read and/or write English or Mandarin and (2) the cancer patients they were providing care to have attended NCCS for at least 1 month. Exclusion criteria were: (1) domestic maids or helpers who were paid to take care of the patients and (2) caregivers of walk-in patients.

Data were collected by trained research assistants after confirmation of their eligibility criteria with the patients during their clinic visit. Consenting caregivers were invited to self-administer the questionnaire in a language of their preference (English or Chinese). The explanation was given about the purpose of the study, the voluntary nature and non-participation would not compromise the care and treatment of the patient, the anonymity of data collection and the procedures including how to fill up the questionnaire. For those patients whose caregivers met the eligibility criteria but did not accompany the patients during their clinic visit, the questionnaire with its explanatory note was given to the patients in a pre-paid envelope to bring home for the caregivers to complete. Ethical approval was obtained from the Centralized Institutional Review Board of the Singapore Health Services. Exemption from written consent was obtained as no identifiable data were collected.

Survey participants were those who had responded either yes or no to the question 'Did you ever search for cancer information?' in the questionnaire were included in this study. Participants who responded with missing response to this question were excluded from this study. Participants who responded that they have searched for information were further asked when was their most recent search, the actual source used during their search and the information sought, their most preferred source for cancer information and their experience with the information search.

Questions on information searching behaviours in the study were adapted based on a survey conducted by Hesse et al [30]. Modifications were made on the sources of the information that were commonly available in our local setting, and refinement was made based on our study aims including an open-ended question on the type of information sought. For caregivers who have not conducted any cancer information search, their reasons for not doing so were collected.

Demographics of respondents were also collected: age, sex, race, marital status, highest education level attained, economic status, monthly household income, housing type and relationship to cancer patient.

Descriptive statistics are used to summarise the characteristics of study participants and type of information searched for. Categorical characteristics were compared between the two groups of caregivers based on Fisher's exact test. Continuous characteristics were compared using Mann-Whitney $\mathrm{U}$ test. All analyses were performed using SAS version 9.4 [31].

\section{Results}

\section{Demographics of information seekers versus non-seekers}

Compared with caregivers who have ever searched for cancer information, the non-searchers tended to be older (median: 40 versus 55 years; $p<0.001)$, had primary and below qualifications $(2.9 \%$ versus $14 \% ; p<0.001)$ and residing in public Housing Development Board (HDB) 3 -room or smaller flats (14\% versus $23 \% ; p<0.001$ ) (Table 1 ). A high percentage of caregivers who have ever searched for cancer information were children taking care of their parents with cancer ( $57 \%$ versus $25 \% ; p<0.001$ ) (Table 1 ). 
Table 1. Characteristics of caregivers by whether caregiver has searched for cancer information.

\begin{tabular}{|c|c|c|c|c|c|c|}
\hline \multirow[t]{2}{*}{ Variable } & \multirow[t]{2}{*}{ Category } & \multicolumn{2}{|c|}{$\begin{array}{l}\text { Searcher } \\
(N=785)\end{array}$} & \multicolumn{2}{|c|}{$\begin{array}{c}\text { Non-searcher } \\
(N=180)\end{array}$} & \multirow[t]{2}{*}{$p$-value } \\
\hline & & No. & $\%$ & No. & $\%$ & \\
\hline \multirow[t]{7}{*}{ Age, years } & $\leq 30$ & 179 & 22.5 & 34 & 18.9 & \multirow[t]{6}{*}{$<0.001$} \\
\hline & $>30-\leq 40$ & 205 & 25.8 & 17 & 9.4 & \\
\hline & $>40-\leq 50$ & 202 & 25.4 & 21 & 11.7 & \\
\hline & $>50-\leq 60$ & 103 & 13.0 & 42 & 23.3 & \\
\hline & $>60$ & 48 & 6.0 & 49 & 27.2 & \\
\hline & Missing & 58 & 7.3 & 17 & 9.4 & \\
\hline & Median (range) ${ }^{1}$ & \multicolumn{2}{|c|}{$40(14-76)$} & \multicolumn{2}{|c|}{$55(18-84)$} & $<0.001$ \\
\hline \multirow[t]{3}{*}{ Sex } & Male & 357 & 44.9 & 78 & 43.3 & \multirow[t]{3}{*}{0.218} \\
\hline & Female & 434 & 54.6 & 99 & 55.0 & \\
\hline & Missing & 4 & 0.5 & 3 & 1.7 & \\
\hline \multirow[t]{5}{*}{ Race } & Chinese & 581 & 73.1 & 130 & 72.2 & \multirow[t]{5}{*}{0.930} \\
\hline & Malays & 117 & 14.7 & 27 & 15.0 & \\
\hline & Indians & 47 & 5.9 & 11 & 6.1 & \\
\hline & Others & 35 & 4.4 & 7 & 3.9 & \\
\hline & Missing & 15 & 1.9 & 5 & 2.8 & \\
\hline \multirow[t]{5}{*}{ Marital status } & Single & 305 & 38.4 & 55 & 30.6 & \multirow[t]{5}{*}{0.001} \\
\hline & Married & 461 & 58.0 & 106 & 58.9 & \\
\hline & Widowed & 4 & 0.5 & 5 & 2.8 & \\
\hline & Divorced/separated & 16 & 2.0 & 6 & 3.3 & \\
\hline & Missing & 9 & 1.1 & 8 & 4.4 & \\
\hline \multirow{6}{*}{$\begin{array}{l}\text { Highest education } \\
\text { attained }\end{array}$} & No formal education & 5 & 0.6 & 8 & 4.4 & \multirow[t]{6}{*}{$<0.001$} \\
\hline & Primary & 18 & 2.3 & 17 & 9.4 & \\
\hline & Secondary & 79 & 9.9 & 50 & 27.8 & \\
\hline & Post-secondary & 239 & 30.1 & 61 & 33.9 & \\
\hline & Tertiary & 441 & 55.5 & 34 & 18.9 & \\
\hline & Missing & 13 & 1.6 & 10 & 5.6 & \\
\hline \multirow[t]{8}{*}{ Economic status } & Full time & 531 & 66.8 & 68 & 37.8 & \multirow[t]{8}{*}{$<0.001$} \\
\hline & Part time & 41 & 5.2 & 11 & 6.1 & \\
\hline & Schooling & 46 & 5.8 & 17 & 9.4 & \\
\hline & Unemployed & 36 & 4.5 & 11 & 6.1 & \\
\hline & Retired & 46 & 5.8 & 32 & 17.8 & \\
\hline & Homemaker & 51 & 6.4 & 23 & 12.8 & \\
\hline & Others & 27 & 3.4 & 5 & 2.8 & \\
\hline & Missing & 17 & 2.1 & 13 & 7.2 & \\
\hline
\end{tabular}


Table 1. Characteristics of caregivers by whether caregiver has searched for cancer information. (Continued)

\begin{tabular}{|c|c|c|c|c|c|c|}
\hline \multirow{10}{*}{$\begin{array}{l}\text { Gross monthly } \\
\text { household income, \$ }\end{array}$} & Not applicable & 171 & 21.5 & 81 & 45.0 & \multirow[t]{10}{*}{$<0.001$} \\
\hline & $\leq 1,000$ & 16 & 2.0 & 7 & 3.9 & \\
\hline & $>1,000-\leq 2,000$ & 34 & 4.3 & 3 & 1.7 & \\
\hline & $>2,000-\leq 3,000$ & 59 & 7.4 & 12 & 6.7 & \\
\hline & $>3,000-\leq 4,000$ & 83 & 10.4 & 18 & 10.0 & \\
\hline & $>4,000-\leq 6,000$ & 155 & 19.5 & 16 & 8.9 & \\
\hline & $>6,000-\leq 8,000$ & 93 & 11.7 & 8 & 4.4 & \\
\hline & $>8,000-\leq 10,000$ & 40 & 5.0 & 3 & 1.7 & \\
\hline & $>10,000$ & 65 & 8.2 & 7 & 3.9 & \\
\hline & Missing & 79 & 9.9 & 25 & 13.9 & \\
\hline \multirow[t]{6}{*}{ Housing type } & HDB 1- \& 2-room flats & 11 & 1.4 & 7 & 3.9 & \multirow[t]{6}{*}{$<0.001$} \\
\hline & HDB 3-room flats & 100 & 12.6 & 34 & 18.9 & \\
\hline & HDB 4-room flats & 273 & 34.3 & 51 & 28.3 & \\
\hline & HDB 5-room flats & 214 & 26.9 & 43 & 23.9 & \\
\hline & Private housing & 173 & 21.8 & 27 & 15.0 & \\
\hline & Missing & 24 & 3.0 & 18 & 10.0 & \\
\hline \multirow{7}{*}{$\begin{array}{l}\text { Relationship to } \\
\text { cancer patient }\end{array}$} & Parent & 47 & 5.9 & 11 & 6.1 & \multirow[t]{7}{*}{$<0.001$} \\
\hline & Child & 451 & 56.7 & 45 & 25.0 & \\
\hline & Sibling & 53 & 6.7 & 18 & 10.0 & \\
\hline & Spouse/partner & 152 & 19.1 & 62 & 34.4 & \\
\hline & Friend & 16 & 2.0 & 8 & 4.4 & \\
\hline & Others & 63 & 7.9 & 30 & 16.7 & \\
\hline & Missing & 13 & 1.6 & 6 & 3.3 & \\
\hline \multirow[t]{3}{*}{ Living with cancer patient } & Yes & 496 & 62.4 & 107 & 59.4 & \multirow[t]{3}{*}{0.011} \\
\hline & No & 289 & 36.4 & 64 & 35.6 & \\
\hline & Missing & 10 & 1.3 & 9 & 5.0 & \\
\hline $\begin{array}{l}\text { No. of household members } \\
\text { (among caregivers who lived } \\
\text { with their patients) }\end{array}$ & Median (range) ${ }^{1}$ & \multicolumn{2}{|c|}{$4(1-10)$} & \multicolumn{2}{|c|}{$3(1-8)$} & 0.013 \\
\hline \multirow[t]{3}{*}{ Type of caregiver } & Primary & 228 & 28.7 & 43 & 23.9 & \multirow[t]{3}{*}{0.004} \\
\hline & Non-primary & 544 & 68.4 & 122 & 67.8 & \\
\hline & Missing & 23 & 2.9 & 15 & 8.3 & \\
\hline \multirow[t]{6}{*}{ Duration of care, years } & $\leq 0.5$ & 183 & 23.0 & 40 & 22.2 & \multirow[t]{6}{*}{0.391} \\
\hline & $>0.5-\leq 1$ & 123 & 15.5 & 24 & 13.3 & \\
\hline & $>1-\leq 3$ & 176 & 22.1 & 33 & 18.3 & \\
\hline & $>3-\leq 5$ & 112 & 14.1 & 26 & 14.4 & \\
\hline & $>5$ & 183 & 23.0 & 49 & 27.2 & \\
\hline & Missing & 18 & 2.3 & 8 & 4.4 & \\
\hline
\end{tabular}


Table 1. Characteristics of caregivers by whether caregiver has searched for cancer information. (Continued)

\begin{tabular}{|c|c|c|c|c|c|c|}
\hline \multicolumn{7}{|l|}{ Type of care: } \\
\hline \multirow[t]{3}{*}{ Companionship } & Yes & 734 & 92.3 & 158 & 87.8 & \multirow[t]{3}{*}{0.097} \\
\hline & No & 46 & 5.8 & 15 & 8.3 & \\
\hline & Missing & 15 & 1.9 & 7 & 3.9 & \\
\hline \multirow[t]{3}{*}{ Transportation } & Yes & 632 & 79.5 & 122 & 67.8 & \multirow[t]{3}{*}{0.003} \\
\hline & No & 148 & 18.6 & 51 & 28.3 & \\
\hline & Missing & 15 & 1.9 & 7 & 3.9 & \\
\hline \multirow[t]{3}{*}{ Homemaking } & Yes & 353 & 44.4 & 74 & 41.1 & \multirow[t]{3}{*}{0.214} \\
\hline & No & 427 & 53.7 & 99 & 55.0 & \\
\hline & Missing & 15 & 1.9 & 7 & 3.9 & \\
\hline \multirow[t]{3}{*}{ Personal care assistance } & Yes & 104 & 13.1 & 19 & 10.6 & \multirow[t]{3}{*}{0.186} \\
\hline & No & 676 & 85.0 & 154 & 85.6 & \\
\hline & Missing & 15 & 1.9 & 7 & 3.9 & \\
\hline \multirow[t]{3}{*}{ Healthcare assistance } & Yes & 221 & 27.8 & 32 & 17.8 & \multirow[t]{3}{*}{0.006} \\
\hline & No & 559 & 70.3 & 141 & 78.3 & \\
\hline & Missing & 15 & 1.9 & 7 & 3.9 & \\
\hline \multirow[t]{3}{*}{ Financial assistance } & Yes & 414 & 52.1 & 51 & 28.3 & \multirow[t]{3}{*}{$<0.001$} \\
\hline & No & 366 & 46.0 & 122 & 67.8 & \\
\hline & Missing & 15 & 1.9 & 7 & 3.9 & \\
\hline \multirow[t]{3}{*}{ Others } & Yes & 5 & 0.6 & 2 & 1.1 & \multirow[t]{3}{*}{0.163} \\
\hline & No & 775 & 97.5 & 171 & 95.0 & \\
\hline & Missing & 15 & 1.9 & 7 & 3.9 & \\
\hline \multirow{5}{*}{$\begin{array}{l}\text { Time spent on caregiving per } \\
\text { week, hours }\end{array}$} & $\leq 5$ & 150 & 18.9 & 33 & 18.3 & \multirow[t]{5}{*}{0.002} \\
\hline & $>5-\leq 20$ & 309 & 38.9 & 45 & 25.0 & \\
\hline & $>20-\leq 40$ & 122 & 15.3 & 37 & 20.6 & \\
\hline & $>40$ & 192 & 24.2 & 56 & 31.1 & \\
\hline & Missing & 22 & 2.8 & 9 & 5.0 & \\
\hline \multirow[t]{5}{*}{ Health status } & Excellent & 200 & 25.2 & 38 & 21.1 & \multirow[t]{5}{*}{0.005} \\
\hline & Good & 340 & 42.8 & 65 & 36.1 & \\
\hline & Satisfactory & 223 & 28.1 & 58 & 32.2 & \\
\hline & Poor & 13 & 1.6 & 9 & 5.0 & \\
\hline & Missing & 19 & 2.4 & 10 & 5.6 & \\
\hline \multirow{4}{*}{$\begin{array}{l}\text { Impact of caregiving } \\
\text { on health status }\end{array}$} & Made it better & 45 & 5.7 & 4 & 2.2 & \multirow[t]{4}{*}{0.050} \\
\hline & Did not affect it & 661 & 83.1 & 148 & 82.2 & \\
\hline & Made it worse & 67 & 8.4 & 18 & 10.0 & \\
\hline & Missing & 22 & 2.8 & 10 & 5.6 & \\
\hline
\end{tabular}

${ }^{1}$ Among patients with non-missing data. 


\section{Demographics of Internet information-seekers versus non-Internet seekers}

Compared to caregivers who have ever searched for cancer information but have never used the Internet to conduct search, online seekers were younger (median: 47 versus 39 years; $p<0.001$ ), had tertiary education (39\% versus $58 \% ; p<0.001$ ) and residing in public HDB 5 -room flats or private housing (38\% versus 50\%; $p=0.05$ ) (Table 2). A higher percentage of the non-online seekers had been taking care of their cancer patients for $>5$ years $(42 \%$ versus $21 \% ; p<0.001)$ and not providing healthcare assistance to their patients $(83 \%$ versus $69 \% ; p$ $=0.025$ ) (Table 2).

Table 2. Characteristics of caregivers who have searched for information by whether caregiver has used Internet for information search in the last 1 year.

\begin{tabular}{|c|c|c|c|c|c|c|}
\hline \multirow{2}{*}{ Variable } & \multirow{2}{*}{ Category } & \multicolumn{2}{|c|}{ Yes $(N=694)$} & \multicolumn{2}{|c|}{ No $(N=82)$} & \multirow{2}{*}{$p$-value } \\
\hline & & No. & $\%$ & No. & $\%$ & \\
\hline \multirow[t]{7}{*}{ Age, years } & $\leq 30$ & 169 & 24.4 & 8 & 9.8 & \multirow[t]{6}{*}{$<0.001$} \\
\hline & $>30-\leq 40$ & 189 & 27.2 & 13 & 15.9 & \\
\hline & $>40-\leq 50$ & 178 & 25.6 & 21 & 25.6 & \\
\hline & $>50-\leq 60$ & 83 & 12.0 & 16 & 19.5 & \\
\hline & $>60$ & 31 & 4.5 & 14 & 17.1 & \\
\hline & Missing & 44 & 6.3 & 10 & 12.2 & \\
\hline & Median (range) ${ }^{1}$ & \multicolumn{2}{|c|}{39 (14-73) } & \multicolumn{2}{|c|}{$47(18-76)$} & $<0.001$ \\
\hline \multirow[t]{3}{*}{ Sex } & Male & 314 & 45.2 & 33 & 40.2 & \multirow[t]{3}{*}{0.626} \\
\hline & Female & 376 & 54.2 & 49 & 59.8 & \\
\hline & Missing & 4 & 0.6 & 0 & - & \\
\hline \multirow[t]{5}{*}{ Race } & Chinese & 510 & 73.5 & 60 & 73.2 & \multirow[t]{5}{*}{0.025} \\
\hline & Malays & 105 & 15.1 & 10 & 12.2 & \\
\hline & Indians & 34 & 4.9 & 11 & 13.4 & \\
\hline & Others & 32 & 4.6 & 1 & 1.2 & \\
\hline & Missing & 13 & 1.9 & 0 & - & \\
\hline \multirow[t]{5}{*}{ Marital status } & Single & 276 & 39.8 & 25 & 30.5 & \multirow[t]{5}{*}{0.143} \\
\hline & Married & 394 & 56.8 & 53 & 64.6 & \\
\hline & Widowed & 3 & 0.4 & 1 & 1.2 & \\
\hline & Divorced/separated & 15 & 2.2 & 1 & 1.2 & \\
\hline & Missing & 6 & 0.9 & 2 & 2.4 & \\
\hline \multirow{6}{*}{$\begin{array}{l}\text { Highest education } \\
\text { attained }\end{array}$} & No formal education & 3 & 0.4 & 2 & 2.4 & \multirow[t]{6}{*}{$<0.001$} \\
\hline & Primary & 11 & 1.6 & 7 & 8.5 & \\
\hline & Secondary & 58 & 8.4 & 16 & 19.5 & \\
\hline & Post-secondary & 213 & 30.7 & 22 & 26.8 & \\
\hline & Tertiary & 400 & 57.6 & 32 & 39.0 & \\
\hline & Missing & 9 & 1.3 & 3 & 3.7 & \\
\hline
\end{tabular}


Table 2. Characteristics of caregivers who have searched for information by whether caregiver has used Internet for information search in the last 1 year. (Continued)

\begin{tabular}{|c|c|c|c|c|c|c|}
\hline \multirow[t]{8}{*}{ Economic status } & Full time & 480 & 69.2 & 40 & 48.8 & \multirow[t]{8}{*}{$<0.001$} \\
\hline & Part time & 37 & 5.3 & 2 & 2.4 & \\
\hline & Schooling & 44 & 6.3 & 2 & 2.4 & \\
\hline & Unemployed & 30 & 4.3 & 6 & 7.3 & \\
\hline & Retired & 35 & 5.0 & 10 & 12.2 & \\
\hline & Homemaker & 31 & 4.5 & 18 & 22.0 & \\
\hline & Others & 25 & 3.6 & 0 & - & \\
\hline & Missing & 12 & 1.7 & 4 & 4.9 & \\
\hline \multirow{10}{*}{$\begin{array}{l}\text { Gross monthly } \\
\text { household income, \$ }\end{array}$} & Not applicable & 142 & 20.5 & 26 & 31.7 & \multirow[t]{10}{*}{0.009} \\
\hline & $\leq 1,000$ & 14 & 2.0 & 1 & 1.2 & \\
\hline & $>1,000-\leq 2,000$ & 34 & 4.9 & 0 & - & \\
\hline & $>2,000-\leq 3,000$ & 52 & 7.5 & 6 & 7.3 & \\
\hline & $>3,000-\leq 4,000$ & 76 & 11.0 & 5 & 6.1 & \\
\hline & $>4,000-\leq 6,000$ & 136 & 19.6 & 13 & 15.9 & \\
\hline & $>6,000-\leq 8,000$ & 83 & 12.0 & 8 & 9.8 & \\
\hline & $>8,000-\leq 10,000$ & 38 & 5.5 & 1 & 1.2 & \\
\hline & $>10,000$ & 59 & 8.5 & 6 & 7.3 & \\
\hline & Missing & 60 & 8.6 & 16 & 19.5 & \\
\hline \multirow[t]{6}{*}{ Housing type } & HDB 1- \& 2-room flats & 10 & 1.4 & 1 & 1.2 & \multirow[t]{6}{*}{0.050} \\
\hline & HDB 3-room flats & 92 & 13.3 & 8 & 9.8 & \\
\hline & HDB 4-room flats & 227 & 32.7 & 36 & 43.9 & \\
\hline & HDB 5-room flats & 192 & 27.7 & 18 & 22.0 & \\
\hline & Private housing & 156 & 22.5 & 13 & 15.9 & \\
\hline & Missing & 17 & 2.4 & 6 & 7.3 & \\
\hline \multirow{7}{*}{$\begin{array}{l}\text { Relationship to } \\
\text { cancer patient }\end{array}$} & Parent & 38 & 5.5 & 5 & 6.1 & \multirow[t]{7}{*}{0.001} \\
\hline & Child & 415 & 59.8 & 30 & 36.6 & \\
\hline & Sibling & 43 & 6.2 & 7 & 8.5 & \\
\hline & Spouse/partner & 115 & 16.6 & 31 & 37.8 & \\
\hline & Friend & 15 & 2.2 & 1 & 1.2 & \\
\hline & Others & 57 & 8.2 & 6 & 7.3 & \\
\hline & Missing & 11 & 1.6 & 2 & 2.4 & \\
\hline \multirow{3}{*}{$\begin{array}{l}\text { Living with } \\
\text { cancer patient }\end{array}$} & Yes & 426 & 61.4 & 57 & 69.5 & \multirow[t]{3}{*}{0.283} \\
\hline & No & 259 & 37.3 & 24 & 29.3 & \\
\hline & Missing & 9 & 1.3 & 1 & 1.2 & \\
\hline $\begin{array}{l}\text { No. of household members } \\
\text { (among caregivers who lived } \\
\text { with their patients) }\end{array}$ & Median (range) ${ }^{1}$ & \multicolumn{2}{|c|}{$4(1-10)$} & \multicolumn{2}{|c|}{$4(2-10)$} & 0.586 \\
\hline
\end{tabular}


Table 2. Characteristics of caregivers who have searched for information by whether caregiver has used Internet for information search in the last 1 year. (Continued)

\begin{tabular}{|c|c|c|c|c|c|c|}
\hline \multirow[t]{2}{*}{ Type of caregiver } & Primary & 199 & 28.7 & 23 & 28.0 & \multirow[t]{3}{*}{1.000} \\
\hline & Non-primary & 475 & 68.4 & 57 & 69.5 & \\
\hline & Missing & 20 & 2.9 & 2 & 2.4 & \\
\hline \multirow[t]{6}{*}{ Duration of care, years } & $\leq 0.5$ & 174 & 25.1 & 7 & 8.5 & \multirow[t]{6}{*}{$<0.001$} \\
\hline & $>0.5-\leq 1$ & 114 & 16.4 & 6 & 7.3 & \\
\hline & $>1-\leq 3$ & 157 & 22.6 & 14 & 17.1 & \\
\hline & $>3-\leq 5$ & 86 & 12.4 & 20 & 24.4 & \\
\hline & $>5$ & 147 & 21.2 & 34 & 41.5 & \\
\hline & Missing & 16 & 2.3 & 1 & 1.2 & \\
\hline \multicolumn{7}{|l|}{ Type of care: } \\
\hline \multirow[t]{3}{*}{ Companionship } & Yes & 636 & 91.6 & 80 & 97.6 & \multirow[t]{3}{*}{0.141} \\
\hline & No & 44 & 6.3 & 1 & 1.2 & \\
\hline & Missing & 14 & 2.0 & 1 & 1.2 & \\
\hline \multirow[t]{3}{*}{ Transportation } & Yes & 548 & 79.0 & 68 & 82.9 & \multirow[t]{3}{*}{0.815} \\
\hline & No & 132 & 19.0 & 13 & 15.9 & \\
\hline & Missing & 14 & 2.0 & 1 & 1.2 & \\
\hline \multirow[t]{3}{*}{ Homemaking } & Yes & 306 & 44.1 & 38 & 46.3 & \multirow[t]{3}{*}{0.933} \\
\hline & No & 374 & 53.9 & 43 & 52.4 & \\
\hline & Missing & 14 & 2.0 & 1 & 1.2 & \\
\hline \multirow[t]{3}{*}{ Personal care assistance } & Yes & 89 & 12.8 & 11 & 13.4 & \multirow[t]{3}{*}{0.955} \\
\hline & No & 591 & 85.2 & 70 & 85.4 & \\
\hline & Missing & 14 & 2.0 & 1 & 1.2 & \\
\hline \multirow[t]{3}{*}{ Healthcare assistance } & Yes & 202 & 29.1 & 13 & 15.9 & \multirow[t]{3}{*}{0.025} \\
\hline & No & 478 & 68.9 & 68 & 82.9 & \\
\hline & Missing & 14 & 2.0 & 1 & 1.2 & \\
\hline \multirow[t]{3}{*}{ Financial assistance } & Yes & 363 & 52.3 & 40 & 48.8 & \multirow[t]{3}{*}{0.770} \\
\hline & No & 317 & 45.7 & 41 & 50.0 & \\
\hline & Missing & 14 & 2.0 & 1 & 1.2 & \\
\hline \multirow[t]{3}{*}{ Others } & Yes & 4 & 0.6 & 1 & 1.2 & \multirow[t]{3}{*}{0.655} \\
\hline & No & 676 & 97.4 & 80 & 97.6 & \\
\hline & Missing & 14 & 2.0 & 1 & 1.2 & \\
\hline \multirow{5}{*}{$\begin{array}{l}\text { Time spent on caregiving } \\
\text { per week, hours }\end{array}$} & $\leq 5$ & 132 & 19.0 & 13 & 15.9 & \multirow[t]{5}{*}{0.025} \\
\hline & $>5-\leq 20$ & 278 & 40.1 & 22 & 26.8 & \\
\hline & $>20-\leq 40$ & 105 & 15.1 & 13 & 15.9 & \\
\hline & $>40$ & 159 & 22.9 & 32 & 39.0 & \\
\hline & Missing & 20 & 2.9 & 2 & 2.4 & \\
\hline
\end{tabular}


Table 2. Characteristics of caregivers who have searched for information by whether caregiver has used Internet for information search in the last 1 year. (Continued)

\begin{tabular}{|c|c|c|c|c|c|c|}
\hline \multirow[t]{5}{*}{ Health status } & Excellent & 178 & 25.6 & 21 & 25.6 & \multirow[t]{5}{*}{0.335} \\
\hline & Good & 304 & 43.8 & 29 & 35.4 & \\
\hline & Satisfactory & 185 & 26.7 & 29 & 35.4 & \\
\hline & Poor & 10 & 1.4 & 2 & 2.4 & \\
\hline & Missing & 17 & 2.4 & 1 & 1.2 & \\
\hline \multirow{4}{*}{$\begin{array}{l}\text { Impact of caregiving } \\
\text { on health status }\end{array}$} & Made it better & 41 & 5.9 & 3 & 3.7 & \multirow[t]{4}{*}{0.651} \\
\hline & Did not affect it & 572 & 82.4 & 73 & 89.0 & \\
\hline & Made it worse & 60 & 8.6 & 5 & 6.1 & \\
\hline & Missing & 21 & 3.0 & 1 & 1.2 & \\
\hline
\end{tabular}

${ }^{1}$ Among patients with non-missing data.

\section{Information-seeking patterns of caregivers}

Of the 986 responded caregivers, 180 (18\%) did not ever search for cancer information (Table 3). Common reasons why these caregivers did not undertake information search were 'trust HCPs more than other sources' (64\%) and 'HCPs provide enough information' (59\%) (Table 4).

\section{Source and preferred source of information}

Among the 795 caregivers who have ever searched for cancer information, about half of these caregivers (54\%) have searched information on the Internet, and another 15\% have obtained their information from HCPs (Figure 1). A total of 371 (47\%) caregivers have used their preferred source of information to conduct their most recent information search. Among the $217(27 \%)$ caregivers who did not use their preferred source, a large number $(n=164)$ of these caregivers' preferred source was 'HCPs'. While most caregivers generally had a good experience with their information search-42\% disagreed that it took a lot of effort to get the information they needed, $47 \%$ disagreed that they were frustrated during the information search and $43 \%$ disagreed that the information found were too hard to understand, about $41 \%$ agreed that they were concerned about the quality of information they have found.

Table 3. Ever search for cancer information.

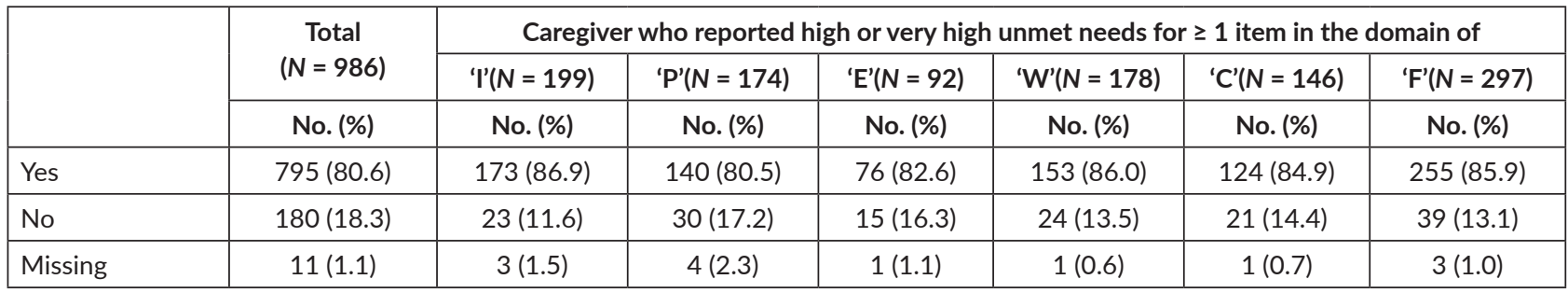

I, information; P, personal; E, emotional; W, work \& finance; C, access \& continuity of healthcare; F, future. 
Table 4. Reason for not searching for cancer information among non-searchers.

\begin{tabular}{|c|c|c|c|c|c|c|c|}
\hline & \multirow{2}{*}{$\begin{array}{c}\text { Total } \\
(N=180)\end{array}$} & \multicolumn{6}{|c|}{ Caregiver who reported high or very high unmet needs for $\geq 1$ item in the domain of } \\
\hline & & 'I'(N= 23) & 'P'(N=30) & 'E'(N = 15) & 'W'(N=24) & 'C'(N=21) & 'F'(N = 39) \\
\hline & No. (\%) & No. (\%) & No. (\%) & No. (\%) & No. (\%) & No. (\%) & No. (\%) \\
\hline $\begin{array}{l}\text { Healthcare professionals } \\
\text { provide enough info }\end{array}$ & $107(59.4)$ & 9 (39.1) & $16(53.3)$ & $7(46.7)$ & $15(62.5)$ & $11(52.4)$ & $23(59.0)$ \\
\hline $\begin{array}{l}\text { Trust healthcare } \\
\text { professionals more than } \\
\text { other sources }\end{array}$ & $115(63.9)$ & $10(43.5)$ & $19(63.3)$ & $8(53.3)$ & $15(62.5)$ & $11(52.4)$ & $22(56.4)$ \\
\hline No computer & $13(7.2)$ & $1(4.3)$ & 4 (13.3) & $1(6.7)$ & $2(8.3)$ & $3(14.3)$ & $3(7.7)$ \\
\hline $\begin{array}{l}\text { Have computer but no } \\
\text { Internet access }\end{array}$ & $2(1.1)$ & $0(-)$ & $1(3.3)$ & $0(-)$ & $0(-)$ & $0(-)$ & $0(-)$ \\
\hline $\begin{array}{l}\text { Not acquainted } \\
\text { with Internet }\end{array}$ & 34 (18.9) & $9(39.1)$ & $10(33.3)$ & $6(40.0)$ & $6(25.0)$ & 7 (33.3) & $10(25.6)$ \\
\hline Others & $32(17.8)$ & $6(26.1)$ & $6(20.0)$ & $1(6.7)$ & $3(12.5)$ & $4(19.0)$ & $9(23.1)$ \\
\hline
\end{tabular}

I, information; P, personal; E, emotional; W, work \& finance; C, access \& continuity of healthcare; F, future.

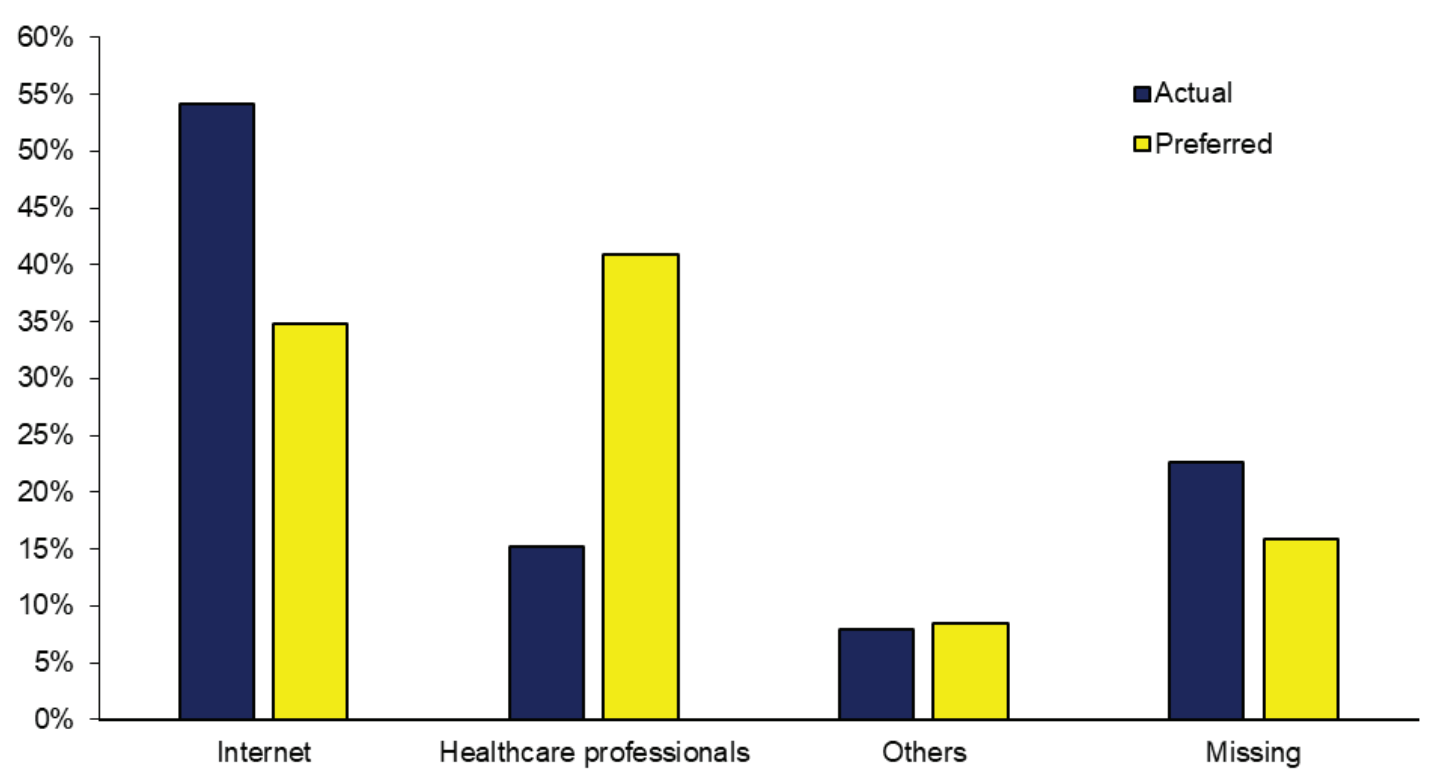

Figure 1. Source of information in most recent search. 


\section{Online health information-seeking}

A high percentage of the 795 caregivers (87\%) had used Internet to search for information about the disease of the patient they were taking care for in the last year prior to the survey. The main reason for the use of Internet by these caregivers was its convenience and accessibility (91\%), and majority (71\%) relied on search engines to search for the information they needed. A high percentage (46\%) of these caregivers was concerned about the quality of information they have found on the Internet (Figure 2).

\section{Amongst caregivers with high or very high unmet needs by domains}

Compared with overall cohort, there were a higher percentage of caregivers within each domain who agreed that they were concerned about the information found. The remaining information-seeking behaviours of caregivers with high or very high unmet needs in each domain of unmet needs were broadly similar as those of the overall cohort (Supplementary Tables A and B).

\section{Type of information searched}

A free response question 'What information did you look for?' yielded 703 respondents. The top three topics being searched are treatment (35.6\%), disease (35.6\%) and side effects (26.5\%) as shown in Table 5.

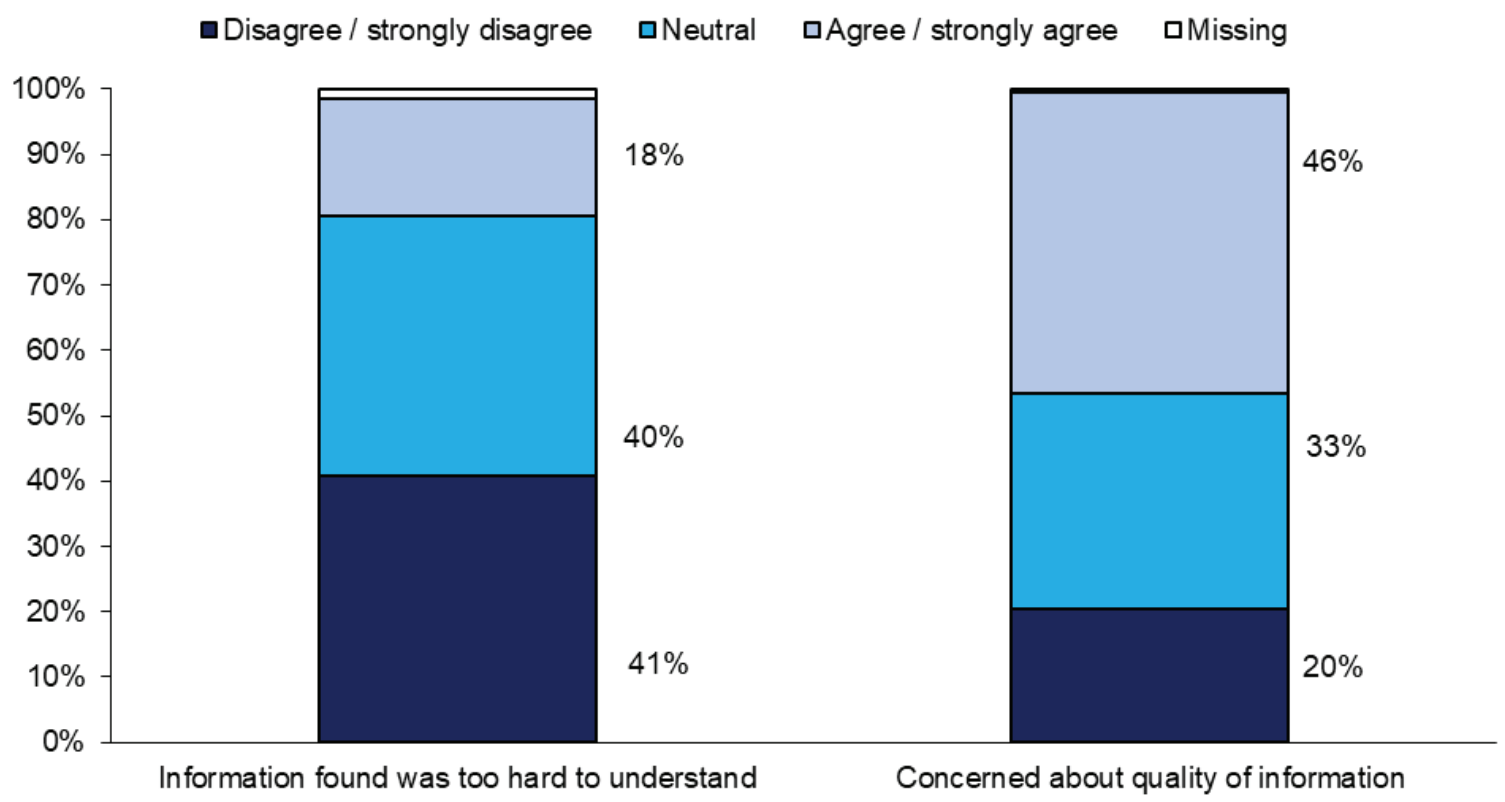

Figure 2. Internet search experience amongst searchers who have used Internet in last 1 year. 
Table 5. Type of information searched.

\begin{tabular}{|l|c|}
\hline \multicolumn{1}{|c|}{ Category } & Responses $^{1}$ \\
\hline Treatment & $250(35.6 \%)$ \\
\hline Disease & $250(35.6 \%)$ \\
\hline Side effects & $186(26.5 \%)$ \\
\hline Nutrition & $177(25.2 \%)$ \\
\hline Cancer statistics & $103(14.7 \%)$ \\
\hline Coping and support & $97(13.8 \%)$ \\
\hline Complementary and alternative medicine & $58(8.3 \%)$ \\
\hline Everything related to cancer & $31(4.4 \%)$ \\
\hline Caregivers & $29(4.1 \%)$ \\
\hline Others & $54(7.7 \%)$ \\
\hline
\end{tabular}

${ }^{1}$ Total responses do not add to 703 as respondents may search for more than one type of information.

\section{Discussion}

Information is essential for coping with cancer. The results of this survey support previous research that caregivers of cancer patients have information needs while providing care and support to the patients.

Health Information-seeking is prevalent amongst cancer caregivers. Only 18\% did not search for cancer information and the main reasons were their trust in HCPs and they received adequate information from these professionals. Trust in HCPs was also cited by non-seekers in other studies [26, 32]. Hillen et al [33] reported that cancer patients trusted their physicians because the physicians were perceived to be technically competent, honest, displayed facilitative behaviours and had established a continuous relationship with them [33]. Trust is found to be associated with facilitation of the medical-decision making process, less worry about treatment, facilitate and improve treatment adherence and reduce the inclination to seek second opinion. Our study also revealed that non-searchers tended to be older, received lower education and residing in HDB 3-room or smaller flats. These flats are publicly developed by the government to provide affordable housing for the citizens. There are a variety of flat types which cater to different household sizes and budgets. This is in concordance with literature [19, 32, 34]. In Zilinski's [34] review, cancer information non-seekers tended to be older, of lower income and received a lower level of education, and typically reported a high level of satisfaction and trust in doctor. Chen's [19] study suggests that older caregivers tended to rely and trust HCPs due possibility to the authority of the information source.

Trust in HCPs may also be the reason why $40.9 \%$ of seekers preferred to receive information from them. The preference for HCPs is well reported in literature [16, 20, 30, 35, 36] as they are perceived to be the most trusted source to received health information [21, 37, 38]. However, only $15.2 \%$ of cancer caregivers were only able to obtain information from this preferred source. The accessibility of physicians may pose challenging for these caregivers due to the physicians' busy schedule and heavy workload. Additionally, physicians are often unable to fully satisfy this desire for information because of the limited time available during clinical encounters especially so in an ambulatory care setting as evidenced by $25.5 \%$ of Internet information seekers gave that as one of the reasons. Our finding is supported by other studies [ 27 , $35,39]$. Therefore, caregivers may have to resort to the Internet to obtain health information as evidenced that although $34.8 \%$ preferred to use the Internet, instead, $54.2 \%$ of caregivers actually used it. The finding that only $47 \%$ caregivers have used their preferred source to conduct their most recent information search indicates a mismatch and gap in service delivery.

Unlike Western culture which emphasises independence as a means to maintain self-esteem and to avoid becoming a burden to their children, in the Asian context, elderly parents look forward to having their children to provide and care for them. Children are brought up with the expectation to provide for and take care of their parents. As such it is not surprising that our study reveals more than half of the caregivers are 
children and they make up a high percentage of caregivers who have ever searched for cancer information. The majority of caregivers sought cancer specific information, namely, treatment, disease, and side effects and demonstrating the importance of such information as well as suggesting unmet information needs relating to the above topics. This finding is supported by literature [20, 35, 40-45]. Such information is needed to become more knowledgeable about the cancer, and, how best to help loved ones. Not having this information results in increased anxiety and stress for family caregivers [42]. As revealed, most of the health information sought for relates to the patients and only a small portion of caregivers sought health information for themselves. This may suggest that caregivers may have a tendency to neglect their own well-being while providing care and warrants further studies.

A high percentage of the caregivers (87\%) had used Internet to search for information about the disease of the patient they were taking care for in the last year prior to the survey. Caregivers reported varying reasons and preferences for receiving information about cancer through the Internet. Besides being the gateway for an inexhaustible volume of information, convenience and accessibility is the top main reason for Internet use. Internet is readily accessible in Singapore as $91 \%$ of households have Internet access and $84 \%$ of individuals are Internet users [46] and can easily be found in homes, offices, schools, libraries and many other locations. Moreover, the widespread availability and usage of smartphones together with the proliferation of low-cost data plans have made the Internet more accessible. Our study also reveals that online seekers were younger, had tertiary education, and residing in HDB 5-room flats or private housing. This is supported by literature. Internet seekers are younger [30, 34, 38, 47], more educated [23, 30, 34, 38, 47], higher income/ higher economic status [30, 34, 38, 47] and Internet accessible at home [34].Despite the availability of many health-related websites, the majority (71\%) of caregivers relied on search engines to search for the information, with less than half using only established medical portal. Although increased access to health information can be helpful, the quality of information varies significantly between sources $[49,50]$. The risk of using search engine is that a caregiver viewing that particular website may be influenced by its order of appearance on major search engines, with most web users only visited the top 10 websites listed in the search results [50]. Moreover, there is a lack of quality control of the medical and health information that is posted on the Internet, and anyone with access can establish a website and post medical information on the Internet [35]. There is also the variability of information with some being evidenced based while others can be unreliable and commercial in nature [28, 49]. This resulted in inconsistency in the quality of information being made available to the public. Even though $41.4 \%$ of caregivers claimed that the information found was not too hard to understand, they may not possess the scientific background needed to interpret the research/ information they retrieved. Besides, they may also lack the critical appraisal skills to distinguish the reliability of the webpage and if the information obtained is reliable [28].

This is a valid concern as reflected in our results that while most caregivers generally had a good experience with their information search, about $41 \%$ agreed that they were concerned about the quality of information they have found, with a high percentage (46\%) of these caregivers was concerned about the quality of information they have found on the Internet. As caregivers are a primary source of support to cancer patients and are the first responders to changes in the patient's status throughout each phase of the cancer care trajectory, they would require the knowledge and skills to care and support them. With limited access to HCPs to obtain information or opportunity to clarify information obtained from other sources, it is important to recognize this need and develop strategies to better support these caregivers. With the proliferation and readily access of information through the Internet and caregivers' lack the needed skills to distinguish if the information obtained is reliable; besides making high-quality information available to both patients and their caregivers, strategies to mitigate the risks of unreliable information may include making available a list of high quality and accurate information web resources and establishing guidelines on how to evaluate health information from the Internet. In addition, in view of the diminished access to HCPs, strategies to address caregivers' information needs also may include a more active role of the Cancer Helpline that is available within the institution.

\section{Limitations}

Several limitations are inherent in this study. This is a cross-sectional study at a single point in time as we did not follow them over time as information needs may differ across cancer trajectory. The sample was also recruited from a single institution in Singapore which limits its ability to generalize to other settings and to all cancer caregivers. In addition, this report is a part of a larger study, and factors that may preclude a more comprehensive understanding may be excluded. Further studies should include the usefulness and trust of the information searched, reasons for the preference in the source, and the reasons why HCPs' provision of information is inadequate. Notwithstanding these 
limitations, with the large sample size, it is, therefore, reasonable to assume that our results provide a reliable evidence of the informationseeking behaviours of caregivers of cancer patients and illuminates key needs and areas for improvement.

\section{Conclusion}

The study concludes that caregivers of cancer patients are actively involved in information search indicating a need for information while providing care and support to the cancer patient. In addition, slightly more than a quarter of information searchers who used the Internet reason for doing so was the information provided by HCPs is insufficient. This implies that either additional or more detailed information to aid in learning and to assist in fulfilling their caregiving roles is needed. Less than half of caregivers have used their preferred source when conducting their most recent information search with the greatest mismatch being found in the HCPs. Caregivers indicated preferring to receive information from HCPs than informal resources such as the Internet. They resorted to the Internet to help address their information needs; however, they were concerned with the quality of information obtained. These further re-enforce the challenges confronting the caregivers and the support needed as they seek information to provide the needed care and support to the cancer patients. As caregivers play a crucial role in providing care and support to the cancer patient, and their ability to render care and support may be compromised by their lack of knowledge and skill, thus it is critical for HCPs to recognise, respect, assess, and address their information needs. It is also important to develop standardised information based on caregivers' identified needs and deliver the information in various health formats so that information is readily available. Moreover, information delivery must also be in the manner and through the mode that is in accordance to their preference. In addition, given the high rates of Internet information-seeking, our finding suggests that this may be an ideal platform to deliver high-quality information, interventions, and reliable health related web-links for the younger, educated, and better off socioeconomically.

To the best of our knowledge, the present study is the first to examine the prevalence of health information-seeking of cancer caregivers and their preferred source for receiving information. The present study adds knowledge to the information-seeking behaviour of caregivers of cancer patients and the reasons for doing or not doing so.

\section{Acknowledgments}

The authors express our sincere gratitude to the National Cancer Centre Research Fund for enabling the conduct of this study. The authors thank all our caregivers who participated in this study and the patients they care for. The authors are also grateful for the administrative support provided by May Jin.

\section{Conflicts of interest}

The authors declare no conflict of interest.

\section{Funding declaration}

This study was funded by the National Cancer Centre Research Fund (NCCRF-YR2018-JAN-PG6). The National Cancer Centre Research Fund has no role in the design, conduct and analysis of the study.

\section{Ethical consideration}

Ethical consent was obtained from the SingHealth Centralised Institutional Review Board (CIRB) prior to the study. Waiver of written informed consent was obtained as no personal identifiers of respondents were obtained. 


\section{References}

1. Akechi T, Akizuki N, and Okamura M, et al (2006) Psychological distress experienced by families of cancer patients: preliminary findings from psychiatric consultation of a cancer center hospital Jpn J Clin Oncol 36(5) 329-332 https://doi.org/10.1093/jjco/hyl029 PMID: 16735370

2. Frioriksdottir N, Saevarsdottir P, and Halfdanardottir SI, et al (2011) Family members of cancer patients: needs, quality of life and symptoms of anxiety and depression Acta Oncol 50(2) 252-258 https://doi.org/10.3109/0284186X.2010.529821

3. Park CH, Shin DW, and Choi JY, et al (2012) Determinants of the burden and positivity of family caregivers of terminally ill cancer patients in Korea Psycho-Oncology 21(3) 282-290 https://doi.org/10.1002/pon.1893 PMID: 22383270

4. Arian M, Younesi SJ, and Khanjani MS (2017) Explaining the experiences and consequences of care among family caregivers of patients with cancer in the terminal phase: a qualitative research Int J Cancer Nurs 10(10) e10753

5. Honea NJ (2015) Caregiver Burden A Guide to Oncology Symptom Management, 2nd edn, ed CG Brown (Pennsylvania: Oncology Nursing Society) pp 143-169.

6. Given BA, Given CW, and Sherwood P (2012) The challenge of quality cancer care for family caregivers Semin Oncol Nurs 28(4) 205-212 https://doi.org/10.1016/j.soncn.2012.09.002 PMID: 23107177

7. van Ryn M, Sanders S, and Kahn K, et al (2011) Objective burden, resources, and other stressors among informal cancer caregivers: a hidden quality issue? Psycho-Oncology 20(1) 44-52 https://doi.org/10.1002/pon.1703

8. Lopez V, Copp G, and Molassiotis A (2012) Male caregivers of patients with breast and gynecologic cancer: experiences from caring from their spouses and partners Cancer Nurs 35(6) 402-410 https://doi.org/10.1097/NCC.0b013e318231daf0

9. Rhee YS, Yun YH, and Park S, et al (2008) Depression in family caregivers of cancer patients: the feeling of burden as a predictor of depression J Clin Oncol 26(36) 5890-5895 https://doi.org/10.1200/JCO.2007.15.3957 PMID: 19029423

10. Chen SC, Tsai MC, and Liu CL, et al (2009) Support needs of patients with oral cancer and burden to their family caregivers Cancer Nurs 32(6) 473-481 https://doi.org/10.1097/NCC.0b013e3181b14e94 PMID: 19816161

11. Lund L, Ross L, Peterson MA, and Groenvold M (2014) Cancer caregiving tasks and consequences and their associations with caregiver status and the caregiver's relationship to the patient: a survey BMC Cancer 14 541. https://doi.org/10.1186/1471-2407-14-541

12. Doubova SV, Aguirre-Hernandez R, and Infante-Castaneda C, et al (2015) Needs of caregivers of cancer patients: validation of the Mexican version of the Support Person Unmet Needs Survey (SPUNS-SFM) Support Care Cancer 23(10) 2925-2935 https://doi.org/10.1007/ s00520-015-2658-0 PMID: 25716339

13. Kim H and Yi M (2015) Unmet needs and quality of life of family caregivers of cancer patients in South Korea Asia Pac J Oncol Nurs 2(3) 152-159 https://doi.org/10.4103/2347-5625.158019 PMID: 27981109 PMCID: 5123473

14. Ashrafian S, Feizollahzadeh $\mathrm{H}$, and Rahmani $\mathrm{A}$, et al (2018) The unmet needs of the family caregivers of patients with cancer visiting a referral hospital in Iran Asia Pac J Oncol Nurs 5 342-352 https://doi.org/10.4103/apjon.apjon_7_18 PMID: 29963598 PMCID: 5996589

15. Campbell HS, Sanson-Fisher R, and Taylor-Brown J, et al (2009) The cancer support person's unmet needs survey: psychometric properties Cancer 115(4) 3351-3359 https://doi.org/10.1002/cncr.24386 PMID: 19472397

16. Longacre $M$ (2013) Cancer caregivers information needs and resource preferences J Cancer Educ 28(2) 297-305 https://doi.org/10.1007/ s13187-013-0472-2 PMID: 23553000 PMCID: 3665756

17. Loke AY, Liu CF, and Szeto Y (2003) The difficulties faced by informal caregivers of patients with terminal cancer in Hong Kong and the available social support Cancer Nurs 26(4) 276-283 https://doi.org/10.1097/00002820-200308000-00004 PMID: 12886118 
18. Sklenarova H, Krumpelmann A, and Haun MW, et al (2015) When do we need to care about the caregiver? Supportive care needs, anxiety, and depression among informal caregivers of patients with cancer and cancer survivors Cancer 121(9) 1513-1519 https://doi. org/10.1002/cncr.29223 PMID: 25677095

19. Chen SC (2014) Information needs and information sources of family caregivers of cancer patients Aslib J Inform 66(6) 623-639 https:// doi.org/10.1108/AJIM-08-2013-0075

20. Chua GP, Tan HK, and Gandhi M (2018) Information sources and online information seeking behaviours of cancer patients in Singapore Ecancermedicalscience 12880 https://doi.org/10.3332/ecancer.2018.880 PMID: 30483360 PMCID: 6214676

21. Shea-Budgell MA, Kostaras X, and Myhill KP, et al (2014) Information needs and sources of information for patients during cancer follow-up Curr Oncol 21(4) 165-173 https://doi.org/10.3747/co.21.1932 PMID: 25089098 PMCID: 4117614

22. Roach AR, Lykins ELB, and Gochett CG, et al (2009) Differences in cancer information seeking behaviour, preferences and awareness between cancer survivors and healthy controls: a national, population-based survey J Cancer Educ 24(1) 73-79 https://doi. org/10.1080/08858190802664784 PMID: 19259869 PMCID: 3315685

23. Knijnenburg SL, Kremer LC, and van den Bos C, et al (2010) Health information needs of childhood cancer survivors and their family Pediatr Blood Cancer 54(1) 123-127 https://doi.org/10.1002/pbc.22207

24. Chiu Y (2011) Probing, impelling but not offending doctors: the role of the internet as an information source for patients' interactions with doctors Qual Health Res 21(12) 1658-1666 https://doi.org/10.1177/1049732311417455 PMID: 21799204

25. Schook RM, Linssen C, and Schramel FMNH, et al (2014) Why do patients and caregivers seek answers from the internet and online lung specialists? A qualitative study. J Med Internet Res 16(2) e37 https://doi.org/10.2196/jmir.2842 PMID: 24496139 PMCID: 3936275

26. Mayer DK, Terrin NC, and Kreps GL, et al (2007) Cancer survivors information seeking behaviours: a comparison of survivors who do and do not seek information about cancer Patient Educ Couns 65(3) 342-350 https://doi.org/10.1016/j.pec.2006.08.015

27. Huang GJ and Penson DF (2008) Internet health resources and the cancer patient Cancer Invest 26(2) 202-207 https://doi. org/10.1080/07357900701566197 PMID: 18259953

28. O'Mathuna DP (2018) How should clinicians engage with online health information? AMA J Ethics 20(11) E1059-E1066 https://doi. org/10.1001/amajethics.2018.1059

29. Kovacs J (1998) Search engines: their necessity and potential danger. A case for regulation or the need for non-commercial alternatives? Thesis Berkman Klein Center-Harvard University.

30. Hesse BW, Arora NK, and Beckjord EB, et al (2008) Information support for cancer survivors Cancer 112(11 Suppl) 2529-2540 https:// doi.org/10.1002/cncr.23445 PMID: 18428201

31. SAS Institute Inc (2019) SAS version 9.4 [https://www.sas.com/en_sg/home.html] Date accessed: 02/07/19

32. Ramanadhan S and Viswanath K (2009) Health and the information nonseeker: a profile Health Commun 20 131-139 https://doi. org/10.1207/s15327027hc2002_4

33. Hillen MA, de Haes HCJM, and Smets EMA (2010) Cancer patients' trust in their physician-a review Psycho-Oncology 20(3) 227-241 https://doi.org/10.1002/pon.1745

34. Zilinski L (2010) Information behaviours of cancer patients in the information age. Libr Stud J [https://works.bepress.com/Izilinski/3/]

35. Lopez-Gomez M, Ortega C, and Suarez I, et al (2012) Internet use by cancer patients: should oncologists 'prescribe' accurate web sites in combination with chemotherapy? A survey in a Spanish cohort Ann Oncol 23 1579-1585 https://doi.org/10.1093/annonc/mdr532 
36. Kinnane NA and Milne DJ (2010) The role of the internet in supporting and informing carers of people with cancer: a literature review Support Care Cancer 18 1123-1136 https://doi.org/10.1007/s00520-010-0863-4 PMID: 20336326

37. Sattar S, Alibha SMH, and Fitch M, et al (2017) Chemotherapy and radiation treatment decision-making experiences of older adults with cancer: a qualitative study J Geriatr Oncol http://dx.doi.org/10.1016/j.jgo.2017.07.013 PMID: 28830737

38. Hesse BW, Nelson DE, and Kreps GL, et al (2005) Trust and sources of health information: the impact of the internet and its implications for health care providers: findings from the first Health Information National Trends Survey Arch Intern Med 165(22) 2618-2624 https://doi.org/10.1001/archinte.165.22.2618 PMID: 16344419

39. Sommerhalder K, Abraham A, and Zufferey MC, et al (2009) Internet information and medical consultation: experiences from patients' and physicians' perspectives. Patient Educ Couns 77(2) 266-271 https://doi.org/10.1016/j.pec.2009.03.028 PMID: 19411157

40. Wang T, Molassiotis A, and Chung BPM, et al (2018) Unmet care needs of advanced cancer patients and their informal caregivers: a systematic review BMC Palliat Care 17(1) 96 https://doi.org/10.1186/s12904-018-0346-9 PMID: 30037346 PMCID: 6057056

41. Lambert SD, Harrison JD, and Smith E, et al (2012) The unmet needs of partners and caregivers of adults diagnosed with cancer: a systematic review BMJ Support Palliat Care 2(3) 224-230 https://doi.org/10.1136/bmjspcare-2012-000226 PMID: 24654195

42. McCarthy B (2011) Family members of patients with cancer: what they know, how they know and what they want to know Eur J Oncol Nurs 15 428-441 https://doi.org/10.1016/j.ejon.2010.10.009

43. Maddock C, Lewis I, and Ahmad K, et al (2011) Online information needs of cancer patients and their organisations Ecancermedicalscience 5235

44. Li PWC, So WKW, and Fong DYT, et al (2011) The information needs of breast cancer patients in Hong Kong and their levels of satisfaction with the provision of information Cancer Nurs 34(1) 49-57 https://doi.org/10.1097/NCC.0b013e3181ef77a0

45. Lo AC, Olson R, and Feldman-Stewart D, et al (2017) A patient-centered approach to evaluate the information needs of women with ductal carcinoma in situ Am J Clin Oncol 40(6) 574-581 https://doi.org/10.1097/COC.0000000000000184

46. Infocomm Media Development Authority (2019) Infocomm usage-households and individuals [https://www2.imda.gov.sg/infocommmedia-landscape/research-and-statistics/infocomm-usage-households-and-individual] Date accessed: 20/09/19

47. Jacobs W, Amuta AO, and Jeon KC (2017) Health information seeking in the digital age: an analysis of health information seeking behaviour among US adults Cogent Soc Sci 3 1-11

48. Fahy E, Hardikar R, and Fox A, et al (2014) Quality of patient health information on the internet: reviewing a complex and evolving landscape Australas Med J 7(1) 24-28 https://doi.org/10.4066/AMJ.2014.1900 PMID: 24567763 PMCID: 3920473

49. Atack L, Luke R, and Chien E (2008) Evaluation of patient satisfaction with tailored online patient education information CIN Comput Inform Nurs 25(6) 258-264 https://doi.org/10.1097/01.NCN.0000304838.52207.90

50. Eysenbach G (2003) The impact of the internet on cancer outcomes CA Cancer J Clin 53 356-371 https://doi.org/10.3322/canjclin.53.6.356 


\section{Supplementary Tables}

Table A. Characteristics of searchers for cancer information.

\begin{tabular}{|c|c|c|c|c|c|c|c|c|}
\hline \multirow{3}{*}{ Variable } & \multirow{3}{*}{ Category } & \multirow{2}{*}{$\begin{array}{c}\text { Total } \\
(N=795)\end{array}$} & \multicolumn{6}{|c|}{$\begin{array}{l}\begin{array}{l}\text { Caregiver who reported high or very high unmet needs for } \geq 1 \text { item in the } \\
\text { domain of }\end{array}\end{array}$} \\
\hline & & & $\begin{array}{c}\text { 'l' } \\
(N=173)\end{array}$ & $\begin{array}{c}\text { 'P' } \\
(N=140)\end{array}$ & $\begin{array}{c}\text { 'E' } \\
(N=76)\end{array}$ & $\begin{array}{c}\text { 'W' } \\
(N=153)\end{array}$ & $\begin{array}{c}\text { 'C' } \\
(N=124)\end{array}$ & $\begin{array}{c}\text { 'F' } \\
(N=255)\end{array}$ \\
\hline & & No. (\%) & No. (\%) & No. (\%) & No. (\%) & No. (\%) & No. (\%) & No. (\%) \\
\hline \multirow{5}{*}{$\begin{array}{l}\text { Most recent } \\
\text { search }\end{array}$} & Past 1 month & $333(41.9)$ & $100(57.8)$ & $85(60.7)$ & $51(67.1)$ & $68(44.4)$ & $67(54.0)$ & $138(54.1)$ \\
\hline & $>1$ to 6 months ago & $192(24.2)$ & $41(23.7)$ & $38(27.1)$ & $19(25.0)$ & $45(29.4)$ & $35(28.2)$ & $67(26.3)$ \\
\hline & $>6$ to 12 months ago & $87(10.9)$ & $14(8.1)$ & $6(4.3)$ & $4(5.3)$ & $14(9.2)$ & $11(8.9)$ & $16(6.3)$ \\
\hline & $>12$ months ago & $170(21.4)$ & $15(8.7)$ & $10(7.1)$ & $2(2.6)$ & $23(15.0)$ & $9(7.3)$ & 31 (12.2) \\
\hline & Missing & $13(1.6)$ & $3(1.7)$ & $1(0.7)$ & $0(-)$ & $3(2.0)$ & $2(1.6)$ & $3(1.2)$ \\
\hline \multirow{13}{*}{$\begin{array}{l}\text { Actual source } \\
\text { used in most } \\
\text { recent search }\end{array}$} & Healthcare professionals & $121(15.2)$ & $17(9.8)$ & $18(12.9)$ & $13(17.1)$ & $23(15.0)$ & 15 (12.1) & 35 (13.7) \\
\hline & Someone with cancer & $16(2.0)$ & $6(3.5)$ & $3(2.1)$ & $3(3.9)$ & $4(2.6)$ & $3(2.4)$ & $10(3.9)$ \\
\hline & Books & $4(0.5)$ & $2(1.2)$ & $0(-)$ & $1(1.3)$ & $1(0.7)$ & $0(-)$ & $1(0.4)$ \\
\hline & Cancer helplines & $6(0.8)$ & $4(2.3)$ & $3(2.1)$ & $2(2.6)$ & $4(2.6)$ & $2(1.6)$ & $5(2.0)$ \\
\hline & Family & $7(0.9)$ & $2(1.2)$ & $0(-)$ & $0(-)$ & $1(0.7)$ & $2(1.6)$ & $3(1.2)$ \\
\hline & Internet & $431(54.2)$ & $76(43.9)$ & $66(47.1)$ & $28(36.8)$ & $68(44.4)$ & $55(44.4)$ & $121(47.5)$ \\
\hline & Magazines & $2(0.3)$ & $0(-)$ & $1(0.7)$ & $1(1.3)$ & $0(-)$ & $0(-)$ & $1(0.4)$ \\
\hline & Library & $5(0.6)$ & $1(0.6)$ & $0(-)$ & $0(-)$ & $0(-)$ & $0(-)$ & $0(-)$ \\
\hline & Friend/co-worker & $15(1.9)$ & $7(4.0)$ & $4(2.9)$ & $3(3.9)$ & $4(2.6)$ & $4(3.2)$ & $7(2.7)$ \\
\hline & Brochures/ pamphlets & $3(0.4)$ & $0(-)$ & $0(-)$ & $0(-)$ & $0(-)$ & $0(-)$ & $1(0.4)$ \\
\hline & Newspaper & $2(0.3)$ & $0(-)$ & $1(0.7)$ & $1(1.3)$ & $1(0.7)$ & $0(-)$ & $1(0.4)$ \\
\hline & Others & $3(0.4)$ & $0(-)$ & $0(-)$ & $0(-)$ & $0(-)$ & $0(-)$ & $1(0.4)$ \\
\hline & Missing & $180(22.6)$ & $58(33.5)$ & $44(31.4)$ & $24(31.6)$ & $47(30.7)$ & $43(34.7)$ & $69(27.1)$ \\
\hline \multirow{13}{*}{$\begin{array}{l}\text { Preferred } \\
\text { source }\end{array}$} & Healthcare professionals & $325(40.9)$ & $59(34.1)$ & $54(38.6)$ & $29(38.2)$ & $57(37.3)$ & $48(38.7)$ & $100(39.2)$ \\
\hline & Someone with cancer & $19(2.4)$ & $5(2.9)$ & $2(1.4)$ & $2(2.6)$ & $5(3.3)$ & $2(1.6)$ & $8(3.1)$ \\
\hline & Books & $1(0.1)$ & $0(-)$ & $0(-)$ & $0(-)$ & $0(-)$ & $0(-)$ & $0(-)$ \\
\hline & Cancer helplines & $14(1.8)$ & $7(4.0)$ & $4(2.9)$ & $1(1.3)$ & $6(3.9)$ & $5(4.0)$ & $10(3.9)$ \\
\hline & Family & $6(0.8)$ & $2(1.2)$ & $0(-)$ & $0(-)$ & $1(0.7)$ & $2(1.6)$ & $1(0.4)$ \\
\hline & Internet & $277(34.8)$ & $48(27.7)$ & $37(26.4)$ & $21(27.6)$ & $43(28.1)$ & $30(24.2)$ & $73(28.6)$ \\
\hline & Magazines & $2(0.3)$ & $0(-)$ & $1(0.7)$ & $1(1.3)$ & $0(-)$ & $0(-)$ & $1(0.4)$ \\
\hline & Library & $3(0.4)$ & $0(-)$ & $0(-)$ & $0(-)$ & $0(-)$ & $0(-)$ & $0(-)$ \\
\hline & Friend/co-worker & $7(0.9)$ & $2(1.2)$ & $2(1.4)$ & $1(1.3)$ & $0(-)$ & $0(-)$ & $2(0.8)$ \\
\hline & Brochures/ pamphlets & $8(1.0)$ & $3(1.7)$ & $2(1.4)$ & $0(-)$ & $3(2.0)$ & $1(0.8)$ & $3(1.2)$ \\
\hline & Newspaper & $2(0.3)$ & $0(-)$ & $1(0.7)$ & $1(1.3)$ & $1(0.7)$ & $0(-)$ & $1(0.4)$ \\
\hline & Others & $5(0.6)$ & $1(0.6)$ & $1(0.7)$ & $0(-)$ & $1(0.7)$ & $0(-)$ & $1(0.4)$ \\
\hline & Missing & $126(15.8)$ & $46(26.6)$ & $36(25.7)$ & $20(26.3)$ & $36(23.5)$ & $36(29.0)$ & 55 (21.6) \\
\hline
\end{tabular}


Table A. Characteristics of searchers for cancer information. (Continued)

\begin{tabular}{|c|c|c|c|c|c|c|c|c|}
\hline \multirow{4}{*}{$\begin{array}{l}\text { Actual vs } \\
\text { preferred } \\
\text { source }\end{array}$} & Actual $=$ preferred & $371(46.7)$ & $61(35.3)$ & $54(38.6)$ & $30(39.5)$ & $61(39.9)$ & $41(33.1)$ & $106(41.6)$ \\
\hline & Actual $\neq$ preferred & $217(27.3)$ & $46(26.6)$ & $36(25.7)$ & $19(25.0)$ & $39(25.5)$ & $34(27.4)$ & $69(27.1)$ \\
\hline & $\begin{array}{l}\text { Preferred }= \\
\text { healthcare professionals }\end{array}$ & $164(20.6)$ & $34(19.7)$ & $29(20.7)$ & $15(19.7)$ & $30(19.6)$ & $27(21.8)$ & $53(20.8)$ \\
\hline & $\begin{array}{l}\text { With } \geq 1 \text { missing } \\
\text { data for actual or pre- } \\
\text { ferred source }\end{array}$ & $207(26.0)$ & $66(38.2)$ & $50(35.7)$ & $27(35.5)$ & $53(34.6)$ & $49(39.5)$ & $80(31.4)$ \\
\hline \multicolumn{9}{|c|}{ Information search experience: } \\
\hline \multirow{6}{*}{$\begin{array}{l}\text { It took a lot } \\
\text { of effort to } \\
\text { get the info } \\
\text { needed }\end{array}$} & Strongly disagreed & $37(4.7)$ & $5(2.9)$ & $3(2.1)$ & $2(2.6)$ & $6(3.9)$ & $2(1.6)$ & $9(3.5)$ \\
\hline & Disagree & $296(37.2)$ & $55(31.8)$ & $46(32.9)$ & $26(34.2)$ & $45(29.4)$ & $40(32.3)$ & $89(34.9)$ \\
\hline & Neutral & $324(40.8)$ & $60(34.7)$ & 49 (35.0) & $22(28.9)$ & $54(35.3)$ & $41(33.1)$ & $92(36.1)$ \\
\hline & Agree & $104(13.1)$ & $40(23.1)$ & $33(23.6)$ & $25(32.9)$ & $37(24.2)$ & $32(25.8)$ & $51(20.0)$ \\
\hline & Strongly agree & $16(2.0)$ & $9(5.2)$ & $6(4.3)$ & $0(-)$ & $8(5.2)$ & $7(5.6)$ & $11(4.3)$ \\
\hline & Missing & $18(2.3)$ & $4(2.3)$ & $3(2.1)$ & $1(1.3)$ & $3(2.0)$ & $2(1.6)$ & $3(1.2)$ \\
\hline \multirow{6}{*}{$\begin{array}{l}\text { Felt frustrated } \\
\text { during info } \\
\text { search }\end{array}$} & Strongly disagreed & $47(5.9)$ & $11(6.4)$ & $6(4.3)$ & $3(3.9)$ & $10(6.5)$ & $6(4.8)$ & $12(4.7)$ \\
\hline & Disagree & $329(41.4)$ & $56(32.4)$ & 46 (32.9) & $29(38.2)$ & $46(30.1)$ & $40(32.3)$ & $92(36.1)$ \\
\hline & Neutral & $296(37.2)$ & 55 (31.8) & $52(37.1)$ & $21(27.6)$ & $57(37.3)$ & $41(33.1)$ & $90(35.3)$ \\
\hline & Agree & $91(11.4)$ & $40(23.1)$ & $28(20.0)$ & $19(25.0)$ & $33(21.6)$ & $28(22.6)$ & 49 (19.2) \\
\hline & Strongly agree & $14(1.8)$ & $7(4.0)$ & $5(3.6)$ & $3(3.9)$ & $4(2.6)$ & $7(5.6)$ & $9(3.5)$ \\
\hline & Missing & $18(2.3)$ & $4(2.3)$ & $3(2.1)$ & $1(1.3)$ & $3(2.0)$ & $2(1.6)$ & $3(1.2)$ \\
\hline \multirow{6}{*}{$\begin{array}{l}\text { Info found } \\
\text { was too } \\
\text { hard to under- } \\
\text { stand }\end{array}$} & Strongly disagreed & $28(3.5)$ & $7(4.0)$ & $4(2.9)$ & $2(2.6)$ & $5(3.3)$ & $3(2.4)$ & $9(3.5)$ \\
\hline & Disagree & $312(39.2)$ & $58(33.5)$ & 48 (34.3) & $26(34.2)$ & $50(32.7)$ & 41 (33.1) & $86(33.7)$ \\
\hline & Neutral & $306(38.5)$ & $58(33.5)$ & $51(36.4)$ & $25(32.9)$ & $58(37.9)$ & $44(35.5)$ & $91(35.7)$ \\
\hline & Agree & $113(14.2)$ & $38(22.0)$ & 27 (19.3) & $19(25.0)$ & $31(20.3)$ & $28(22.6)$ & $56(22.0)$ \\
\hline & Strongly agree & $18(2.3)$ & $8(4.6)$ & $7(5.0)$ & $3(3.9)$ & $6(3.9)$ & $6(4.8)$ & $10(3.9)$ \\
\hline & Missing & $18(2.3)$ & $4(2.3)$ & $3(2.1)$ & $1(1.3)$ & $3(2.0)$ & $2(1.6)$ & $3(1.2)$ \\
\hline \multirow{6}{*}{$\begin{array}{l}\text { Concerned } \\
\text { about quality } \\
\text { of info }\end{array}$} & Strongly disagreed & $21(2.6)$ & $6(3.5)$ & $2(1.4)$ & $1(1.3)$ & $3(2.0)$ & $3(2.4)$ & $5(2.0)$ \\
\hline & Disagree & $168(21.1)$ & 22 (12.7) & 17 (12.1) & $7(9.2)$ & $19(12.4)$ & $20(16.1)$ & $33(12.9)$ \\
\hline & Neutral & $265(33.3)$ & $35(20.2)$ & $29(20.7)$ & $17(22.4)$ & $45(29.4)$ & $23(18.5)$ & 59 (23.1) \\
\hline & Agree & $245(30.8)$ & $71(41.0)$ & $63(45.0)$ & $36(47.4)$ & $56(36.6)$ & $51(41.1)$ & $107(42.0)$ \\
\hline & Strongly agree & $78(9.8)$ & $35(20.2)$ & 26 (18.6) & $14(18.4)$ & $27(17.6)$ & $25(20.2)$ & 48 (18.8) \\
\hline & Missing & $18(2.3)$ & $4(2.3)$ & $3(2.1)$ & $1(1.3)$ & $3(2.0)$ & $2(1.6)$ & $3(1.2)$ \\
\hline \multirow{5}{*}{$\begin{array}{l}\text { Use internet } \\
\text { to search info } \\
\text { about patient's } \\
\text { disease in last } \\
1 \text { year }\end{array}$} & Never & $82(10.3)$ & $12(6.9)$ & $7(5.0)$ & $6(7.9)$ & $8(5.2)$ & $7(5.6)$ & $20(7.8)$ \\
\hline & Rarely & $86(10.8)$ & $14(8.1)$ & $7(5.0)$ & $6(7.9)$ & $14(9.2)$ & $12(9.7)$ & $19(7.5)$ \\
\hline & Sometimes & $339(42.6)$ & $80(46.2)$ & $53(37.9)$ & $27(35.5)$ & $71(46.4)$ & $46(37.1)$ & $102(40.0)$ \\
\hline & Often & $269(33.8)$ & 65 (37.6) & 69 (49.3) & $37(48.7)$ & $56(36.6)$ & $57(46.0)$ & $112(43.9)$ \\
\hline & Missing & $19(2.4)$ & $2(1.2)$ & $4(2.9)$ & $0(-)$ & $4(2.6)$ & $2(1.6)$ & $2(0.8)$ \\
\hline
\end{tabular}

I, information; P, personal; E, emotional; W, work \& finance; C, access \& continuity of healthcare; F, future. 
Table B. Characteristics of searchers for cancer information who have used internet in last 1 year.

\begin{tabular}{|c|c|c|c|c|c|c|c|c|}
\hline \multirow{3}{*}{ Variable } & \multirow{3}{*}{ Category } & \multirow{2}{*}{$\begin{array}{c}\text { Total } \\
(N=694)\end{array}$} & \multicolumn{6}{|c|}{$\begin{array}{l}\text { Caregiver who reported high or very high unmet needs for } \geq 1 \text { item in the } \\
\text { domain of }\end{array}$} \\
\hline & & & $\begin{array}{c}\text { 'l’ } \\
(N=159)\end{array}$ & $\begin{array}{c}\text { 'P' } \\
(N=129)\end{array}$ & $\begin{array}{c}\text { 'E' } \\
(N=70)\end{array}$ & $\begin{array}{c}\text { 'W' } \\
(N=141)\end{array}$ & $\begin{array}{c}\text { 'C' } \\
(N=115)\end{array}$ & $\begin{array}{c}\text { ' } F ' \\
(N=233)\end{array}$ \\
\hline & & No. (\%) & No. (\%) & No. (\%) & No. (\%) & No. (\%) & No. (\%) & No. (\%) \\
\hline \multirow{6}{*}{$\begin{array}{l}\text { Reason for us- } \\
\text { ing internet } \\
\text { to search for } \\
\text { info }\end{array}$} & $\begin{array}{l}\text { Info provided by health- } \\
\text { care professionals } \\
\text { is insufficient }\end{array}$ & $177(25.5)$ & $67(42.1)$ & $54(41.9)$ & $32(45.7)$ & $53(37.6)$ & $51(44.3)$ & 91 (39.1) \\
\hline & Convenience $\&$ accessible & $630(90.8)$ & $138(86.8)$ & $114(88.4)$ & $62(88.6)$ & $125(88.7)$ & $98(85.2)$ & $198(85.0)$ \\
\hline & $\begin{array}{l}\text { Protects privacy and } \\
\text { keeps me anonymous }\end{array}$ & $107(15.4)$ & $31(19.5)$ & $30(23.3)$ & $15(21.4)$ & $34(24.1)$ & $35(30.4)$ & 51 (21.9) \\
\hline & $\begin{array}{l}\text { Gateway to an inexhaust- } \\
\text { ible volume of info }\end{array}$ & $272(39.2)$ & 55 (34.6) & $59(45.7)$ & $25(35.7)$ & 49 (34.8) & $52(45.2)$ & $97(41.6)$ \\
\hline & $\begin{array}{l}\text { Info provide is more cur- } \\
\text { rent and reliable }\end{array}$ & $122(17.6)$ & $32(20.1)$ & $26(20.2)$ & $16(22.9)$ & $31(22.0)$ & $22(19.1)$ & $51(21.9)$ \\
\hline & Others & $16(2.3)$ & $7(4.4)$ & $6(4.7)$ & $4(5.7)$ & $6(4.3)$ & $6(5.2)$ & $8(3.4)$ \\
\hline \multirow{5}{*}{$\begin{array}{l}\text { Behaviour } \\
\text { of internet } \\
\text { search }\end{array}$} & Rely on search engines & $495(71.3)$ & $112(70.4)$ & $87(67.4)$ & $47(67.1)$ & $97(68.8)$ & $80(69.6)$ & $156(67.0)$ \\
\hline & $\begin{array}{l}\text { Browse only first few } \\
\text { entries and modify search } \\
\text { words till info needed is } \\
\text { found }\end{array}$ & $225(32.4)$ & $62(39.0)$ & 49 (38.0) & $19(27.1)$ & $48(34.0)$ & $52(45.2)$ & $80(34.3)$ \\
\hline & $\begin{array}{l}\text { Search through many } \\
\text { sites }\end{array}$ & $270(38.9)$ & $68(42.8)$ & $61(47.3)$ & $33(47.1)$ & $66(46.8)$ & $48(41.7)$ & $113(48.5)$ \\
\hline & $\begin{array}{l}\text { Use only established } \\
\text { medical portal }\end{array}$ & $218(31.4)$ & $50(31.4)$ & $51(39.5)$ & $29(41.4)$ & $50(35.5)$ & $44(38.3)$ & 79 (33.9) \\
\hline & Others & $7(1.0)$ & $2(1.3)$ & $3(2.3)$ & $3(4.3)$ & $2(1.4)$ & $3(2.6)$ & $2(0.9)$ \\
\hline \multicolumn{9}{|c|}{ Information search experience: } \\
\hline \multirow{6}{*}{$\begin{array}{l}\text { Info found } \\
\text { was too } \\
\text { hard to under- } \\
\text { stand }\end{array}$} & Strongly disagreed & $25(3.6)$ & $7(4.4)$ & $4(3.1)$ & $2(2.9)$ & $7(5.0)$ & $3(2.6)$ & $10(4.3)$ \\
\hline & Disagree & $262(37.8)$ & 48 (30.2) & $40(31.0)$ & $24(34.3)$ & $46(32.6)$ & $37(32.2)$ & 72 (30.9) \\
\hline & Neutral & $279(40.2)$ & $64(40.3)$ & $46(35.7)$ & $25(35.7)$ & $55(39.0)$ & $44(38.3)$ & $90(38.6)$ \\
\hline & Agree & $118(17.0)$ & $37(23.3)$ & $35(27.1)$ & $18(25.7)$ & $28(19.9)$ & $26(22.6)$ & $55(23.6)$ \\
\hline & Strongly agree & $9(1.3)$ & $2(1.3)$ & $3(2.3)$ & $0(-)$ & $4(2.8)$ & $4(3.5)$ & $5(2.1)$ \\
\hline & Missing & $1(0.1)$ & $1(0.6)$ & $1(0.8)$ & $1(1.4)$ & $1(0.7)$ & $1(0.9)$ & $1(0.4)$ \\
\hline \multirow{6}{*}{$\begin{array}{l}\text { Concerned } \\
\text { about quality } \\
\text { of info }\end{array}$} & Strongly disagreed & $14(2.0)$ & $2(1.3)$ & $1(0.8)$ & $0(-)$ & $2(1.4)$ & $1(0.9)$ & $3(1.3)$ \\
\hline & Disagree & $127(18.3)$ & $17(10.7)$ & $16(12.4)$ & $10(14.3)$ & $20(14.2)$ & $17(14.8)$ & 27 (11.6) \\
\hline & Neutral & $230(33.1)$ & 44 (27.7) & 25 (19.4) & $17(24.3)$ & $41(29.1)$ & $24(20.9)$ & $58(24.9)$ \\
\hline & Agree & $246(35.4)$ & 62 (39.0) & $59(45.7)$ & $29(41.4)$ & $47(33.3)$ & $43(37.4)$ & 98 (42.1) \\
\hline & Strongly agree & $74(10.7)$ & $33(20.8)$ & $28(21.7)$ & $14(20.0)$ & $31(22.0)$ & $30(26.1)$ & 47 (20.2) \\
\hline & Missing & $3(0.4)$ & $1(0.6)$ & $1(0.8)$ & $0(-)$ & $0(-)$ & $0(-)$ & $0(-)$ \\
\hline
\end{tabular}

I, information; P, personal; E, emotional; W, work \& finance; C, access \& continuity of healthcare; F, future. 